\title{
Új célzott terápiás lehetőség az onkológiában: tropomiozin receptor-tirozin-kináz gátlók
}

\author{
Kiss Edina dr. - Pápai Zsuzsanna dr. \\ Magyar Honvédség Egészségügyi Központ, Onkológiai Osztály, Budapest
}

\begin{abstract}
A molekuláris diagnosztikai módszerek folyamatos fejlődésének köszönhetően egyre több onkogén genetikai eltérést azonosítanak. A neurotrofikus tropomiozin receptor-tirozin-kináz (NTRK-) génfúziók fontos precíziós onkológiai célpontok, melyek mindhárom NTRK-génben előfordulhatnak, onkogén-hajtóeróként viselkednek. A génfúziók különböző molekuláris diagnosztikai módszerekkel azonosíthatók, melyek közül a legpontosabb, legköltségesebb és legidőigényesebb meghatározást az újgenerációs szekvenálási technika jelenti. A tropomiozin receptor-tirozin-kináz (TRK-) fúziós fehérjék szelektív gátlása személyre szabott onkológiai kezelési lehetőséget jelent a tumor típusától, lokalizációjától és a beteg életkorától függetlenül. Az első generációs TRK-gátlók gyors, hatékony és tartós daganatellenes hatást biztosítanak kimutatott NTRK-fúzió-pozitív daganatok esetén, alacsony mellékhatásprofil mellett. Az első generációs TRK-gátlók mellett jelentkező 'on target’ rezisztenciát a második generációs TRK-gátlók oldják fel. Szekvenciális tirozin-kináz-inhibitor-kezeléssel tartós betegségmentes túlélés érhető el.
\end{abstract}

Orv Hetil. 2021; 162(34): 1362-1369.

Kulcsszavak: precíziós onkológia, neurotrofikus tropomiozin receptor-tirozin-kináz génfúzió, tropomiozin receptor-tirozin-kináz gátlók, szekvenciális kezelés

\section{Novel targeted therapeutic option in oncology: tropomyosin receptor tyrosine kinase inhibitors}

Due to the continuous development of molecular diagnostic methods, more and more oncogenic genetic abnormalities are being identified. Neurotrophic tropomyosin receptor tyrosine kinase (NTRK) gene fusions are important precision oncology targets that can occur in all three NTRK genes and act as oncogenic drivers. Gene fusions can be identified by a variety of molecular diagnostic technologies, of which next-generation sequencing is the most accurate, costly and time-consuming determination. Selective inhibition of tropomyosin receptor tyrosine kinase (TRK) fusion proteins represents a personalized oncology treatment option regardless of tumour type, localization and patient age. First-generation TRK inhibitors provide rapid, efffective and long-lasting antitumor activity in NTRK fusion-positive tumors with a low side-effect profile. On target resistance to first-generation TRK inhibitors is resolved by second-generation TRK inhibitors. Durable disease-free survival can be achieved with sequential tyrosine kinase inhibitor therapies.

Keywords: precision oncology, neurotrophic tropomyosin receptor kinase gene fusion, tropomyosin receptor kinase inhibitors, sequential therapy

Kiss E, Pápai Zs. [Novel targeted therapeutic option in oncology: tropomyosin receptor tyrosine kinase inhibitors]. Orv Hetil. 2021; 162(34): 1362-1369.

(Beérkezett: 2021. január 18.; elfogadva: 2021. február 22.)

\section{Rövidítések}

ALK = anaplasticus lymphoma kináz; BDNF = (brain-derived neurotrophic factor) agyi eredetû neurotrofikus faktor; BRAF = a B-Raf protoonkogént kódoló gén $; \mathrm{CI}=($ confidence inter- val) konfidenciaintervallum; DNS = dezoxiribonukleinsav; $\mathrm{EMA}=$ (European Medicines Agency) Európai Gyógyszerügynökség; ERK = extracelluláris szignál által regulált kináz; ETV6 = translocation-Ets-leukemia virus; FDA = (U.S. Food 
and Drug Administration) az Amerikai Egyesült Államok Élelmiszer- és Gyógyszerügyi Hivatala; FISH = fluoreszcens in situ hibridizáció; GIST = gastrointestinalis stromalis tumor; KRAS = a K-ras fehérjét kódoló gén; MAPK = (mitogen-activated protein kinase) mitogénaktivált proteinkináz; MEK = MAPK/ ERK kináz; MET = (mesenchymal-epithelial transition) mesenchymalis-epithelialis átmenet; NGF = (neuronal growth factor) idegi növekedési faktor; NGS $=$ (next-generation sequencing) újgenerációs szekvenálás; $\mathrm{NT}=$ neurotrofin; NTRK = neurotrofikus tropomiozin receptor-tirozin-kináz; PI3K = (phosphatidylinositol 3-kinase) foszfatidil-inozitol3-kináz; PLC $\gamma=$ (phospholipase $\mathrm{C}$ gamma) foszfolipáz-Cgamma; RNS = ribonukleinsav; ROS1 = c-ros onkogén- 1 ; RT-PCR $=$ (reverse transcription polymerase chain reaction) reverztranszkripciós polimeráz-láncreakció; TRK = tropomiozin receptor-tirozin-kináz

A szolid tumorok kezelésében jelentős változást láthatunk az utóbbi időben a molekuláris diagnosztikai módszerek fejlődésének köszönhetően, melyek egyre több onkogén genetikai eltérés azonosítását eredményezik [1, 2]. A 'driver' onkogének (onkogén-hajtóerook ) elleni újgenerációs célzott terápiák alapjaiban változtatják meg, individualizálják a daganatok kezelését. A TRK- (tropomiozin receptor-tirozin-kináz) fúziós fehérjék szelektív gátlása személyre szabott, úgynevezett precíziós onkológiai terápiát jelent számos tumortípusban. Forradalmi jelentősége, hogy a korábbi szöveti altípusra vagy lokalizációra alapozott kezelésekkel szemben ez azoktól független, a terápia indikációja a molekuláris célponton alapul $[1,2]$.

Áttörést jelent a célzott terápiák történetében, hogy az FDA (az Egyesült Államok Élelmiszer- és Gyógyszerügyi Hivatala) az első generációs TRK-gátló larotrektinibet 2018. november 26-án, majd az entrektinibet 2019. augusztus 15-én gyorsított eljárással törzskönyvezte molekuláris diagnosztikai módszerekkel kimutatott NTRK(neurotrofikus tropomiozin receptor-tirozin-kináz) génfúzió esetén, a daganat típusától, lokalizációjától és a beteg életkorától függetlenül $[3,4,5]$.

\section{Az NTRK-géncsalád}

Az utóbbi években az NTRK1, NTRK2 és NTRK3 gének által alkotott NTRK 'driver' géncsalád került a figyelem központjába, melyek a humán lq23.1, 9q21.33 és 15q25.3 kromoszómán helyezkednek el, és három, multikináz-funkcióval rendelkező transzmembrán proteint - TRKA/B/C - kódolnak [6].

\section{A TRK-receptorok felépítése és múködése}

A TRKA/B/C növekedésifaktor-receptorok alapvetó szerepet játszanak az idegrendszer fejlődésében és müködésében a neurotrofinok (NT-k) általi aktiválódás révén [6]. Részt vesznek a fájdalom, a propriocepció, az étvágy és a memória szabályozásában [7].
Mindhárom TRK-receptor három részből: egy extracelluláris ligandkötő, egy transzmembrán és egy intracelluláris kinázdoménből épül fel. A TRK-receptorok aktivációját az NT-k kötődése indítja be, melyek az egyes receptorokra specifikusak. A TRKA-t az idegi növekedési faktor (nerve growth factor - NGF), míg a TRKB-t az agyi eredetû neurotrofikus faktor (brain-derived neurotrophic factor - BDNF) és az NT4/5, a TRKC-t pedig az NT3 aktiválja [1, 6]. Az NT kötődése a receptor homodimerizációjához, a kinázdomén foszforilációjához és különböző szignáltranszdukciós útvonalak - mint a MAPK (mitogénaktivált proteinkináz), a PI3K (foszfatidil-inozitol-3-kináz), a PLC $\gamma$ (foszfolipáz-C- $\gamma$ ) - aktivációjához vezet, ami fokozott sejtproliferációt és -differenciálódást, valamint csökkent sejtapoptózist idéz elő $[1,6]$. A fentiekből adódik, hogy a ligand kötődése kulcsfontosságú lépés a jelátviteli kaszkád beindításában.

\section{Az NTRK-génfúzió}

Az NTRK-génfúziók fontos precíziós onkológiai célpontok, a három NTRK-gén bármelyikén előfordulhatnak, de a leggyakrabban az NTRKI és NTRK3 génekben mutathatók ki [8]. A transzlokáció kialakulásához szükség van egy másik génre, úgynevezett fúziós partnerre. A génfúzió kialakulása során az NTRK-gén 3 ' régiójú, kinázt tartalmazó része egy másik gén (fúziós partner) 5 ' régiójával kapcsolódik össze intra- vagy interkromoszomális átrendeződések következtében [1, 2, 6]. Az onkogén fúziók abnormális kimérafehérjék, úgynevezett fúziós proteinek transzkripciójához vezetnek, melyek túlexpresszálódott, folyamatosan aktivált kinázfunkcióval rendelkeznek, onkogén-hajtóeróként viselkednek, folyamatos sejtproliferációt és csökkent sejtapoptózist okoznak, mindezt a ligand kötődésétől függetlenül $[6,8,9]$.

Az NTRK-génfúziók számos tumortípusban előfordulnak, és többféle fúziós partnerrel társulhatnak [8]. Az első NTRK1-génfúziót (TPM3-NTRK1) 1986-ban azonosították humán colorectalis daganatból származó mintában [10].

Fontos kiemelni, hogy a génfúziók nem azonosak a génmutációkkal. Az NTRK-génfúziók onkológiai 'driver' célpontok. A mutációk másodlagos vagy szerzett, a gén kinázdoménjét érintő genetikai eltérések, melyek a korábbi TRK-gátló kezelés hatására alakulnak ki, és rezisztenssé teszik a daganatot a kezeléssel szemben [7].

\section{Az NTRK-tumorok epidemiológiája}

Az NTRK-génfúziók nagyon ritkák, a humán szolid tumorok legfeljebb 1\%-ában mutathatók ki [7, 8]. Számos felnőtt- és gyermekkori daganatban megtalálhatók, gyakoriságuk tumortípusonként változik $[1,2,7,8]$. Előfordulásuk alapján két csoportba oszthatók; a ritka daganatok esetén viszonylag gyakoriak (90\%-nál nagyobb 
prevalencia), például infantilis fibrosarcomában 95100\%-ban jelen vannak. A gyakoribb előfordulású daganatokkal (például tüdö-, colorectalis daganat) azonban ritkán társulnak (5-25\% vagy 5\%-nál kisebb prevalencia) [2].

\section{Az NTRK-génfúzió kimutatása}

Az NTRK-génfúziókat, illetve fúziós fehérjéket számos molekuláris diagnosztikai módszer - mint az immunhisztokémia, a fluoreszcens in situ hibridizáció (FISH), a reverztranszkripciós polimeráz-láncreakció (RT-PCR) és az RNS- vagy DNS-alapú újgenerációs szekvenálás (NGS) - képes kimutatni [6].

\section{Immunhisztokémia}

Az immunhisztokémia az NTRK-génfúzió indirekt jelenlétére, a TRK-fúziós fehérjék kimutatására alkalmas gyors, olcsó, könnyen hozzáférhető, de korlátozott értékű vizsgálat. A pan-TRK-antitestek rutin-szűrővizsgálatként használhatók, de mivel nem tudnak különbséget tenni a vad típusú és a fúziós fehérje között, a pozitív eredményt meg kell erősíteni RNS- vagy DNS-alapú molekuláris metodikával, hogy bizonyított legyen az onkogénfúzió jelenléte a daganatban, tehát önálló tesztként nem alkalmazható $[6,11-13]$.

\section{Fluoreszcens in situ hibridizáció}

A FISH az NTRK-génfúzió kimutatására alkalmas olcsó, széles körben hozzáférhető vizsgálómódszer olyan daganatok esetén, amelyekben az NTRK-génfúziók nagy gyakorisággal vagy visszatérő fúziókkal fordulnak elő [6, 14]. Ilyen például az ETV6-NTRK3 génfúzió, mely az elsőként azonosított génfúziók egyike volt; számos daganattal társul, és FISH-vizsgálattal detektálható $[6,8]$. Ismert fúziós partner kimutatására szolgál elsősorban; nagyrészt egyetlen génfúzió kimutatására alkalmas, ezáltal a három NTRK-gén mindegyikéhez külön próbára van szükség, ami időigényes folyamat $[14,15]$. Új fúziós partner esetén korlátozott értékű vizsgálat. Hátránya, hogy nem bizonyítja, hogy a kromoszómaátrendeződés onkogénfúziót idéz elő $[6,14]$. Előfordulhat álnegatív eredmény - amikor a kis deletiókból származó átrendeződéseket nem tudja kimutatni -, illetve álpozitív eredmény is a nem produktív átrendeződések következtében $[6,14]$.

\section{Reverztranszkripciós polimeráz-láncreakció}

A FISH-vizsgálat alternatívájaként használható az RTPCR-teszt ismert fúziók kimutatására; új fúziós partner esetén nem alkalmazható $[6,15]$.

\section{Újgenerációs szekvenálás}

Az NGS nagy érzékenységú és specificitású technológia, a korábbi genomszekvenálási módszerekhez képest több genetikai célpont egyidejû elemzésére alkalmas [6, 1316). Az NGS meghaladja a FISH érzékenységét, új partnerek azonosítását is lehetővé teszi. A nukleinsavszekvenálás lehet DNS- és RNS-alapú [13-15]. A génfúziókhoz vezető genomiális eltérések többsége az intronokban (nem kódoló genomiális régió) fordul elő, ezen átrendeződések detektálására a DNS-alapú vizsgálatoknak intronokat kell szekvenálniuk. Az intronok azonban gyakran tartalmaznak ismétlődő szekvenciákat, nagy méretűek, ami megnehezíti a vizsgálatot $[6,14$, 15]. Az RNS-alapú szekvenálásnak az az előnye a DNSalapúval szemben, hogy a szekvenálás az intronok helyett a kódoló szekvenciákra (exonok) összpontosul, ezért az intronok nem befolyásolják; az RNS minősége azonban korlátozza. Az NGS pontos, de idő- és költségigényes vizsgálómódszer, mely komoly bioinformatikai hátteret igényel [13-17].

\section{Az NTRK-génfúzió kimutatásának algoritmusa}

Minden technikának vannak tehát előnyei és hátrányai; a vizsgálómódszerek megválasztásakor figyelembe kell venni a rendelkezésre álló lehetőségeket, a génfúziókra jellemző tulajdonságokat, illetve a szakmai ajánlásokat. A legpontosabb, de egyben legköltségesebb módszert az NGS jelenti, mely azonban nem férhető hozzá rutinszerüen.

A nemzetközi ajánlás alapján azokban a daganatokban, amelyekben az NTRK-génfúziók gyakoribb előfordulásúak (például infantilis fibrosarcoma, az emlő és a nyálmirigy secretoros daganata), FISH-vizsgálat ajánlott, ennek pozitív eredménye elfogadható $[6,13]$. Ha a vizsgálómódszer nem érhető el, pan-TRK-immunhisztokémia végezhető alternatív megoldásként - ennek pozitív eredményét, valamint a FISH és a pan-TRK-immunhisztokémia negatív eredményeit NGS-sel kell megerősíteni $[6,13]$. Az alacsony prevalenciájú daganatok esetén lehetőség szerint szekvenálás javasolt; ha ez nem férhető hozzá, akkor pan-TRK-immunhisztokémiával előszürést kell végezni, majd a pozitív eredményt NGS-sel kell validálni $[6,13]$.

A hazai diagnosztikai algoritmus a magas prevalenciájú daganatok esetén első lépésben pan-TRK- vagy töréspont-FISH-vizsgálatot, majd ennek eredményétől függően szekvenálást javasol. Azoknál a daganatoknál, amelyekben az NTRK-génfúzó ritkán fordul elő, de rutinszerüen végeznek molekuláris vizsgálatot (például tüdődaganat), célszerű szélesebb spektrumú, NTRK-géneket is magában foglaló NGS-t alkalmazni. Egyéb tumoroknál pan-TRK-immunhisztokémiai előszűrés javasolt, kivéve a magas, vad típusú TRK-t expresszáló da- 
ganatokat (például neuroendokrin tumor, GIST, agydaganat), mert ezeknél a vizsgálat álpozitív eredményt adhat, tehát a szekvenálás a célravezető metodika [16].

\section{TRK-gátlók}

Az NTRK-génfúziók a rákterápia új célpontjai számos gyermek- és felnőttkori daganat esetében, melyek célzott kinázgátlókkal sikeresen blokkolhatók $[1,2]$. A TRK-inhibitorok mint tumoragnosztikus célzott terápiák forradalmi jelentőséggel bírnak, mivel a daganat lokalizációjától és szövettani altípusától független az alkalmazásuk, csak a molekuláris célpont jelenléte számít [1, 2].

Jelenleg két, FDA- és EMA- (Európai Gyógyszerügynökség) törzskönyvvel rendelkező, első generációs TRKgátlót alkalmazhatunk NTRK-fúziós daganatok kezelésére $[4,5,18]$. A második generációs célzott terápiák jelenleg kísérleti fázisban vannak, az előzetes eredmények nagyon biztatóak [19, 20]. A TRK-inhibitorokra jellemző tulajdonságokat az 1. táblázat foglalja össze.

\section{Első generációs TRK-gátlók}

A larotrektinib és az entrektinib első generációs tirozinkináz-inhibitorok, amelyek nagyon hatékonyak mindhárom vad típusú (nem mutált) TRK ellen [3]. Míg a larotrektinib szelektív pan-TRK-inhibitor, addig az entrektinib emellett ROS1 - és ALK-gátlással is rendelkezik $[3,21,22]$.

\section{Larotrektinib}

A larotrektinib orálisan alkalmazható, kapszula és oldat formájában hozzáférhető, erős és szelektív, központi idegrendszeri aktivitással rendelkező tirozin-kináz-gátló, mely mindhárom TRK-proteinkinázt gátolja $[2,3,7$, $21,23)$. Képes átjutni a vér-agy gáton, így mind primer, mind szekunder központi idegrendszeri daganatok esetén hatékony [24, 25].
Az FDA 2018. november 26-án az első tumoragnosztikus célzott terápiaként törzskönyvezte, molekuláris diagnosztikai módszerekkel kimutatott NTRK-génfúzió esetén, a daganat típusától, lokalizációjától és a beteg életkorától függetlenül inoperábilis vagy metasztatikus betegségnél, amelynél egyéb, hatékony kezelési lehetőség nem áll rendelkezésre [4]. 2019. szeptember 24. óta már európai törzskönyvvel is rendelkezik; hazánkban egyedi méltányossági kérelemmel érhető el [18].

\section{A larotrektinib hatékonysága}

Drilon és mtsai 2018-ban publikálták a larotrektinib tumorellenes aktivitását három, kis betegszámú fázis I-II. klinikai vizsgálat eredményeinek ismertetésével [2, 3, 7]. Egy felnőtt betegek részvételével végzett fázis I., egy gyermekkorú betegeket beválasztó fázis I/II. (SCOUT), valamint egy felnőttek és serdülők körében végzett fázis II. (NAVIGATE) klinikai vizsgálatban 55, larotrektinibbel kezelt, előrehaladott szolid tumoros beteg adatait elemezték [3, 7]. 17 különböző típusú daganatban, köztük infantilis fibrosarcomában, nyálmirigy-, pajzsmirigydaganatban, GIST-ben volt detektálható az NTRKgénfúzió [3]. Az elsődleges végpont, az objektív válaszadási arány a független radiológiai felülvizsgálati bizottság értékelése alapján 75\% (95\% CI: 61-85\%) volt, a vizsgáló értekelése alapján pedig 80\% (95\% CI: 67$90 \%$ ). A válaszidő medián ideje 1,8 hónap volt (tartomány: 0,9-6,4). A válaszokat a tumor típusától, a beteg életkorától vagy az NTRK-fúzió típusától (NTRK1, NTRK2 vagy NTRK3) függetlenül is megfigyelték [3, 7]. A válasz medián időtartamát és a progressziómentes túlélést nem sikerült elérni. A medián 9,4 hónapos követés során a válaszreakcióval rendelkező betegek $86 \%$-a (44 betegból 38 ) folytatta a kezelést, vagy kuratív mútéten esett át $[3,7]$. Mindezen eredmények alapján a larotrektinib volt az első tirozin-kináz-gátló, melyet az FDA, majd az EMA tumoragnosztikus terápiaként törzskönyvezett $[4,18]$.

1. táblázat | TRK-gátlók

\begin{tabular}{lllll}
\hline & Larotrektinib & Entrektinib & $\begin{array}{l}\text { Szelitrektinib } \\
\text { (LOXO-195) }\end{array}$ & Repotrektinib \\
\hline Generáció & 1. & 1. & 2. & 2. \\
\hline Célpont & TRKA/B/C & TRKA/B/C & TRKA/B/C & $\begin{array}{l}\text { TRKA/B/C } \\
\text { ROS1 } \\
\text { ALK }\end{array}$ \\
& & ALK & & \\
\hline Törzskönyv & FDA & FDA & EMA & Igen \\
\hline NTRK-rezisztencia-mutáció gátlása & Nem & Nem & Igen & Makrociklusos \\
\hline Szerkezet & Nem makrociklusos & Nem makrociklusos & Makrociklusos & 355.37 \\
\hline Molekulasúly & 428.44 Da & 560.65 Da & 380.43 Da & Da \\
\hline
\end{tabular}

ALK = anaplasticus lymphoma kináz; Da = Dalton; EMA = Európai Gyógyszerügynökség; FDA = az Egyesült Államok Élelmiszer- és Gyógyszerügyi Hivatala; NTRK = neurotrofikus tropomiozin receptor-tirozin-kináz; ROS1 = c-ros onkogén-1; TRKA/B $/ \mathrm{C}=$ tropomiozin receptor-tirozin-kináz A/B/C 
A kibővített adatbázisban 159 (korábbi 55 + 104 új) beteg adatait dolgozták fel, ebből 153 beteg eredményei voltak értékelhetók. Ez alapján az objektív válaszarány 79\% (95\% CI: 72-85) volt, teljes és részleges választ a betegek 17 és 63\%-ánál figyeltek meg. A válaszokat a kiindulási adatbázis eredményeihez hasonlóan tumoragnosztikusan észlelték. A leggyakrabban az NTRK3 (55\%) és NTRKI génekben (40\%) detektáltak onkogénfúziót, a daganatok döntő többsége (44\%) lágyrész-sarcoma volt. A medián progressziómentes túlélés 28,3 hónap, a teljes túlélés mediánja 44,4 hónap volt, míg a válasz időtartamának mediánja 35,5 hónapnak adódott $[26,27]$.

\section{Entrektinib}

Az entrektinib orális, kapszula formájában alkalmazható, pan-TRK-, ROS1- és ALK-gátló multikináz-inhibitor, mely központi idegrendszeri aktivitással is rendelkezik [2, 3, 5, 7, 27-29]. Az FDA 2019. augusztus 15-én törzskönyvezte NTRK-fúzió-pozitív tumorok kezelésére felnőttek és 12 éves vagy idősebb gyermekek esetén inoperábilis vagy áttétes betegség, valamint ROS1-pozitív felnőttkori, áttétes, nem kissejtes tüdődaganat kezelésére; az EMA 2020. július 31-én engedélyezte ugyanabban az indikációban $[5,30]$.

\section{Az entrektinib hatékonysága}

Az entrektinib hatékonyságát 3, fázis I-II. (ALKA-372001, STARTRK-1 és STARTRK-2) klinikai vizsgálatban értékelték [29, 31]. 54, előrehaladott vagy áttétes NTRK-fúzió-pozitív daganatban szenvedő felnőtt beteg adatait elemezve az objektív válaszadási arány 57\%-nak adódott (95\% CI: 43,2-70,8), ebből 7\%-ban alakult ki teljes és $50 \%$-ban részleges válasz. A válasz medián időtartama 10 hónap (95\% CI: 7,1- nem becsülhető meg), a progressziómentes túlélés mediánja 11 hónap, a teljes túlélés mediánja pedig 21 hónap volt [31].

\section{Az első generációs TRK-inhibitorok intracranialis aktivitása}

Az NTRK-génfúziók jelenlétét nemcsak agyi áttéteket adó extracranialis szolid tumorokban, hanem primer agydaganatokban is igazolták [2,3]. A larotrektinib és az entrektinib is képes átjutni a vér-agy gáton, ezáltal intracranialis betegség esetén is hatékony terápiás gyógysze$\operatorname{rek}[3,24,25,29,32]$.

A larotrektinib klinikai vizsgálataiban 14 értékelhető betegnél volt kimutatható primer és 5 esetben szekunder központi idegrendszeri betegség [3, 24, 25, 32]. Az agyi áttétes betegeknél 3 beteg reagált a kezelésre, így az objektív válaszadási arány 60\% (95\% CI: 15-95) volt [3, 24, 25 ]. Primer agyi folyamat esetén a válaszadási ráta $36 \%$ - nak adódott (95\% CI: 13-65), míg a progressziómentes túlélés medián értéke 11 hónap volt.

Az entrektinibbel végzett klinikai vizsgálatokban a betegek nagyobb hányadában, 22\%-ában $(\mathrm{n}=12 / 54)$ volt kimutatható agyi áttét a kiinduláskor [3, 29, 33]. A terápia mellett az intracranialis objektív válaszadási arány 54,5\% (95\% CI 23,4-83,3) volt; a válasz medián időtartamát nem sikerült elérni, a koponyaûri progressziómentes túlélés mediánja pedig 14,3 hónapnak adódott [3, $29,33]$.

A larotrektinib és az entrektinib tehát intracranialis betegség esetén is hatékonynak bizonyult, tartós betegségkontroll volt megfigyelhető $[3,29,32,33]$.

\section{TRK-rezisztencia}

Annak ellenére, hogy a legtöbb NTRK-pozitív daganat kezdetben nagyon jól reagál, végül rezisztenssé válnak az első generációs TRK-gátlókkal szemben. Ennek gyakran az az oka, hogy a korábbi TRK-inhibitor-terápia során mutációk alakulnak ki [3, 19].

Az 'on-target' rezisztencia az NTRK-gén kinázdoménjének szerzett vagy másodlagos mutációi formájában jön létre. Ezek a mutációk 3 fö helyen - a 'solvent front', a 'gatekeeper' és az aktivációs hurok xDFG -motívumának helyén - aminosav-szubsztitúciókat okoznak, melyek megváltoztatják a kinázdomén konformációját vagy ATP-kötő affinitását, ezáltal stericusan akadályozzák az első generációs szerek bekötődését és hatását [3, 7, 19, 34]. A második generációs TRK-gátlók ezt a rezisztenciát képesek legyőzni a kompaktabb szerkezetnek és a kis molekulasúlynak köszönhetően [3].

Léteznek elsődleges, úgynevezett 'off-target', vagy 'bypass' rezisztenciamechanizmusok is, melyek más receptor-kináz vagy jelátviteli kaszkád mediátorait érintő genomi változások formájában valósulnak meg, konvergens MAPK-útvonal-aktiválást közvetítenek: például $B R A F-, K R A S$-mutáció, a mesenchymalis-epithelialis átmenet (MET-) gén amplifikációja $[3,35]$. A rezisztenciát a MAPK-útvonalat célzó terápiák önmagukban vagy TRK-gátlókkal kombinálva oldhatják fel (például MAPK-MEK gátló + TRK-inhibitor) [35].

\section{Második generációs TRK-gátlók}

A második generációs TRK-inhibitorok kis molekulasúlyú, makrociklusos szerkezetú, orális multikinázgátlók $[36,37]$. Az első generációs TRK-inhibitorokkal szemben szerzett rezisztencia legyőzésére fejleszették ki őket $[3,36,37]$. Kompaktabb molekulaszerkezetüknek és kis méretüknek köszönhetően elkerülik a szerzett mutációk okozta stericus akadályokat, nagy affinitással és pontossággal kötődnek a kinázdomén ATP-kötő zsebébe [3, 19]. Mind a vad típusú, mind a mutált TRK-t gátolják, melyek a ‘downstream' jelátviteli útvonalak megszakadá- 
sához és a daganatos sejtproliferáció gátlásához vezetnek $[36,37]$.

A szelitrektinib (LOXO-195) pan-TRK-inhibitor, a repotrektinib emellett ALK- és ROS1-gátlással is rendelkezik $[3,36,37]$.

\section{A második generációs TRK-gátlók hatékonysága}

A szelitrektinib klinikai hatékonyságát két fázis I. (NCT03211551l és FDA kiterjesztett hozzáférési 'Single Patient Protocol') 'on -going study'-ban vizsgálják [3, 38]. A beválasztott, NTRK-fúzió-pozitív daganattal rendelkező 31 beteg mindegyike korábbi TRK-inhibitor- (larotrektinib, entrektinib, PLX7486) kezelésben részesült. A 29 értékelhető betegnél a teljes válaszadási arány 34\% volt, míg a TRK-kinázdomén-mutációkban szenvedő betegek esetében ez magasabbnak, 45\%-nak adódott [3, 38]. A betegek döntő többségében, 68,9\%-ukban $(n=20 / 29)$ kimutatható volt a kinázmutáció; 3 betegnél a ‘bypass' rezisztencia mutációját azonosították, ez utóbbiak egyike sem reagált a kezelésre $[3,38]$.

A repotrektinib preklinikai aktivitását igazolta, hogy különböző modellekben hatékony in vitro antiproliferatív és in vivo tumorellenes hatást mutatott [39]. A TRIDENT-1 - fázis II., nyílt, multicentrikus, folyamatban lévő - klinikai vizsgálatban a repotrektinib hatékonyságát, biztonságosságát, tolerálhatóságát értékelik ALK-, ROS1-vagy NTRK-fúzió-pozitív, előrehaladott szolid tumoros betegeknél $[40,41]$. A vizsgálat korai, 2020. július 10-i határidővel bezárólag értékelt időközi adataiból látható, hogy a 39 beteg közül 6 betegnél volt kimutatható NTRK-génfúzió; ebben a betegpopulációban 50\% (95\% CI: 12-88\%) volt az objektív válaszadási arány, a válasz időtartama 1,7-3,6 hónap között mozgott [42].

A második generációs TRK-gátlók tehát képesek a kinázdomén-mutációk által közvetített rezisztencia leküzdésére [3, 19]. Az NTRK-génfúziós daganatokban a szekvenciális TRK-inhibitor-terápia paradigmaváltást jelenthet. A folyamatos célzott terápiás kezeléssel tartós betegségkontroll és hosszú túlélés érhető el [3].

\section{Biztonságosság és mellékhatásprofil}

Az első generációs TRK-gátlók a klinikai vizsgálatokban kedvező toxicitási profillal rendelkeztek [3, 7, 27, 31]. Az összesített biztonsági populációban larotrektinibkezelésben 260, míg entrektinibterápiában 355 (ebből 68 az NTRK-pozitív) beteg részesült, a daganat típusától, illetve molekuláris profiljától, NTRK-fúziós állapotától függetlenül. Az összes nemkívánatos esemény döntő többsége 1. és 2 . fokozatú volt, és reverzibilisnek bizonyult [7, 27, 31]. Ezek közül a kezeléssel összefüggő leggyakoribb általános mellékhatás és laboratóriumi elté- rés larotrektinibterápia esetén a fáradékonyság, köhögés, hányinger, hasmenés, aminotranszferáz-emelkedés, anaemia és neutrophilszám-csökkenés volt, entrektinib esetében pedig ízérzészavar, székrekedés, fáradékonyság, perifériás oedema, kreatininemelkedés és anaemia volt gyakrabban észlelhető $[27,31]$.

A leggyakoribb súlyos (grade 3 . vagy 4.) mellékhatás larotrektinibterápia alatt az anaemia (10\%) és a neutrophil fehérvérsejtek számának csökkenése (5\%), míg entrektinibkezelés mellett a vérszegénység (11\%), a nehézlégzés $(6 \%)$ és a fáradékonyság $(4 \%)$ volt $[27,31]$. Larotrektinibkezelés mellett az NTRK-fúzió-pozitív betegek 8\%-ánál, míg az entrektinib esetében ezen populáció 40\%-ánál kellett csökkenteni a kiindulási dózist [27, 31].

\section{A TRK-inhibitor-kezelés célzott mellékhatásai}

A TRK-jelátviteli útvonal fontos szerepet játszik az idegrendszer fejlődésében és múködésében, a fájdalom, a propriocepció, az étvágy és a memória szabályozásában $[6,7]$. A TRK-gátlás következtében célzott, idegrendszeri mellékhatások, mint szédülés, paresthesia, testsúlygyarapodás, kognitív zavarok jelenhetnek meg [3, 7]. Míg az embrionális fejlődés során kialakuló TRK-gátlásnak vagy -vesztésnek súlyos következményei lehetnek, addig a posztembrionális TRK-inhibíció enyhe tüneteket okozhat [2, 3]. Ennek megfelelően a klinikai vizsgálatokban döntően grade 1-2. súlyosságú mellékhatásként jelentkeztek $[3,27,31]$.

A leggyakoribb 'target' mellékhatás a szédülés volt, az első generációs TRK-gátlóval kezelt betegek 24-25\%ában jelentkezett enyhe súlyossággal, a csökkent propriocepció és a kisagy diszfunkciójának következtében [2, $3,27,31]$. A második generációs szelitrektinib fázis I. klinikai vizsgálatában a szédülés/ataxia sokkal gyakoribb volt, a betegek 60-65\%-ában fordult elő, 15-20\%-ában grade 3 . súlyossággal, így dóziskorlátozó toxicitásként regisztrálták $[3,38]$. Paresthesiát és testsúlygyarapodást az entrektinibkezelés során figyeltek meg a betegek 19\%ában $[3,31]$. A súlynövekedés TRKB-gátlás során jelentkezik, mivel részt vesz az étvágy szabályozásában, és a kóros TRKB-aktivitás hyperphagiát, hyperdipsiát, elhízást okoz [3, 7, 43-45]. A TRKB emellett a memória és a hangulat szabályozásában is szerepet játszik [46]. A STARTRK-1 fázis I. klinikai vizsgálatban az entrektinibkezelés mellett grade 3. kognitív zavar dóziskorlátozó toxicitását észlelték [47].

\section{Következtetés}

A személyre szabott, molekuláris diagnosztikai vizsgálatokra alapozott onkológia új szemléletváltozást jelezhet a rákterápiában. Az NTRK-génfúziók fontos 'driver' gén célpontok gyermek- és felnőttkori daganatokban 
egyaránt; gyakoriságuk daganattípusonként változik, a ritka daganatokkal gyakrabban társulnak. A génfúzió különböző molekuláris diagnosztikai módszerekkel detektálható; közülük az NGS adja a legpontosabb eredményt, mely költséges és hosszadalmas folyamat. Az első generációs TRK-gátló larotrektinib és entrektinib FDA- és EMA-törzskönyvvel is rendelkezik. Gyors, erős és tartós daganatellenes aktivitást mutattak, a daganat szövettani típusától, lokalizációjától és a beteg életkorától függetlenül. A tartós betegségkontroll ellenére a betegek egy része végül nem reagál a kezelésre. Ennek hátterében gyakran a korábbi TRK-kezelés mellett kialakuló, szerzett vagy 'on target' rezisztenciamutáció áll. A kinázdomén mutációi által közvetített ellenállás legyőzésére fejlesztették ki a kis molekulasúlyú, makrociklusos, második generációs TRK-inhibitorokat, mint a szelitrektinib és a repotrektinib. Az NTRK-génfúziós daganatokban a szekvenciális TRK-gátló kezelés paradigmaváltás jelenthet. A szekvenciális kezeléssel tartós betegségkontroll és hosszú túlélés érhető el. A TRK-inhibitor-terápia orálisan alkalmazható, jól tolerálható, alacsony mellékhatásprofillal bíró, kényelmes kezelés. Az általános, kezeléssel összefüggő mellékhatások, laboreltérések mellett célzott, neurológiai tüneteket (szédülés, paresthesia, súlygyarapodás) is okozhatnak a TRK-gátlás révén.

Ritka daganatok (például felnőtt- és gyermekkori sarcomák, secretoros emlö- és nyálmirigydaganat) esetén mindenképpen javasolt, de jó általános állapotú, korábbi terápiákra refrakter, áttétes daganatban szenvedő betegeknél is érdemes az NTRK-génfúziók jelenlétének vizsgálata.

Anyagi támogatás: A közlemény megírása anyagi támogatásban nem részesült.

Szerzôi munkamegosztás: K. E.: A szakirodalom felkutatása, elemzése, az összefoglaló közlemény megírása, a táblázat elkészítése. P. Zs.: A kutatás irányítása, szakértői feladat ellátása. A közlemény végleges változatát mindkét szerző elolvasta és jóváhagyta.

Érdekeltségek: A szerzőknek nincsenek érdekeltségeik.

\section{Irodalom}

[1] Amatu A, Sartore-Bianchi A, Siena S. NTRK gene fusions as novel targets of cancer therapy across multiple tumour types. ESMO Open 2016; 1: e000023.

[2] Cocco E, Scaltriti M, Drilon A. NTRK fusion-positive cancers and TRK inhibitor therapy. Nat Rev Clin Oncol. 2018; 15: 731747.

[3] Drilon A. TRK inhibitors in TRK fusion-positive cancers. Ann Oncol. 2019; 30(Suppl 8): viii23-viii30.

[4] U.S. Food and Drug Administration. FDA approves larotrectinib for solid tumors with NTRK gene fusions. Silver Spring, MD, 12/14/2018. Available from: https://www.fda.gov/drugs/ fda-approves-larotrectinib-solid-tumors-ntrk-gene-fusions [accessed: December 14, 2018].
[5] U.S. Food and Drug Administration. FDA approves entrectinib for NTRK solid tumors and ROS-1 NSCLC. Silver Spring, MD, 08/16/2019. Available from: https://www.fda.gov/drugs/resources-information-approved-drugs/fda-approves-entrectinibntrk-solid-tumors-and-ros-1-nsclc [accessed: August 16, 2019].

[6] Penault-Llorca F, Rudzinski ER, Sepulveda AR. Testing algorithm for identification of patients with TRK fusion cancer. J Clin Pathol. 2019; 72: 460-467.

[7] Drilon A, Laetsch TW, Kummar S, et al. Efficacy of larotrectinib in TRK fusion-positive cancers adults and children. N Engl J Med. 2018; 378: 731-739.

[8] Vaishnavi A, Le AT, Doebele RC. TRKing down an old oncogene in a new era of targeted therapy. Cancer Discov. 2015; 5: 25-34.

[9] Stransky N, Cerami E, Schalm S, et al. The landscape of kinase fusions in cancer. Nat Commun. 2014; 5: 4846.

[10] Martin-Zanca D, Hughes SH, Barbacid M. A human oncogene formed by the fusion of truncated tropomyosin and protein tyrosine kinase sequences. Nature 1986; 319: 743-748.

[11] Hechtman JF, Benayed R, Hyman DM, et al. Pan-Trk immunohistochemistry is an efficient and reliable screen for the detection of NTRK fusions. Am J Surg Pathol. 2017; 41: 1547-1551.

[12] Hsiao SJ, Zehir A, Sireci AN, et al. Detection of tumor NTRK gene fusions to identify patients who may benefit from tyrosine kinase (TRK) inhibitor therapy. J Mol Diag. 2019; 21: 553-571.

[13] Marchiò C, Scaltriti M, Ladanyi M, et al. ESMO recommendation on standard methods to detect NTRK fusions in daily practice and clinical research. Ann Oncol. 2019; 30: 1417-1427.

[14] Davies KD, Le AT, Sheren J, et al. Comparison of molecular testing modalities for detection of ROS1 rearrangements in a cohort of positive patient samples. J Thorac Oncol. 2018; 13: 14741482 .

[15] Beadling C, Wald AI, Warrick A, et al. A multiplexed amplicon approach for detecting gene fusions by next-generation sequencing. J Mol Diagn. 2016; 18: 165-175.

[16] Lippai Z, Sápi Z. Diagnostic approach of tumors with neurotrophic tropomyosin receptor tyrosine kinase gene fusion. [A neurotrofikus tropomiozin receptor-tirozin-kináz génfúziót tartalmazó daganatok diagnosztikai megközelítése.] Orv Hetil. 2020; 161: 1753-1763. [Hungarian]

[17] Serratì S, De Summa S, Pilato B, et al. Next-generation sequencing: advances and applications in cancer diagnosis. Onco Targets Ther. 2016; 9: 7355-7365.

[18] European Medicines Agency. Vitrakvi. Amsterdam, 19/09/2019. Available from: https://ema.europa.eu/en/medicines/human/EPAR/vitrakvi [accessed: September 19, 2019].

[19] Drilon A, Nagasubramanian R, Blake JF, et al. A next-generation TRK kinase inhibitor overcomes acquired resistance to prior TRK kinase inhibition in patients with TRK fusion-positive solid tumors. Cancer Discov. 2017; 7: 963-972.

[20] Zhai D, Deng W, Huang J, et al. Abstract 3161: TPX-0005, an ALK/ROS1/TRK inhibitor, overcomes multiple resistance mechanisms by targeting SRC/FAK signaling. Cancer Res. 2017; 77(13 Suppl): 3161 .

[21] Doebele RC, Davis LE, Vaishnavi A, et al. An oncogenic NTRK fusion in a patient with soft-tissue sarcoma with response to the tropomyosin-related kinase inhibitor LOXO-101. Cancer Discov. 2015; 5: 1049-1057.

[22] Menichincheri M, Ardini E, Magnaghi P, et al. Discovery of entrectinib: a new 3-aminoindazole as a potent anaplastic lymphoma kinase (ALK), c-ros oncogene 1 kinase (ROS1), and pantropomyosin receptor kinases (pan-TRKs) inhibitor. J Med Chem. 2016; 59: 3392-3408.

[23] European Medicines Agency. Vitrakvi. Prescribing information. [Vitrakvi. Alkalmazási elóírás.] Amsterdam, 19/09/2019. Available from: https://europa.eu/documents/product-information/vitrakvi-epar-product-information_hu.pdf [accessed: September 19, 2019]. [Hungarian] 
[24] Drilon A, DuBois SG, Farago AF, et al. Activity of larotrectinib in TRK fusion cancer patients with brain metastases or primary central nervous system tumors. J Clin Oncol. 2019; 37(15 Suppl): 2006.

[25] Rosen EY, Schram AM, Young RJ, et al. Larotrectinib demonstrates CNS efficacy in TRK fusion-positive solid tumors. JCO Precis Oncol. 2019; 3: PO.19.00009.

[26] Hyman D, Tan DS, vanTilburg C, et al. Durability of response with larotrectinib in adult and pediatric patients with TRK fusion cancer. Ann Oncol. 2019; 30(Suppl 9): IX123.

[27] Hong DS, DuBois SG, Kummar S, et al. Larotrectinib in patients with TRK fusion-positive solid tumours: a pooled analyses of three phase 1/2 clinical trials. Lancet Oncol. 2020; 21: 531540 .

[28] European Medicines Agency. Rozlytrek. Prescribing information. [Rozlytrek. Alkalmazási elő́rás.] Amsterdam, 31/07/2020 Available from: https://ema.europa.eu/en/documents/product-information/rozlytrek-epar-product-information_hu.pdf [accessed: July 31, 2020]. [Hungarian]

[29] Demetri GD, Paz-Ares L, Farago AF, et al. Efficacy and safety of entrectinib in patients with NTRK fusion-positive tumours: pooled analysis of STARTRK-2, STARTRK-1, and ALKA-372001. Ann Oncol. 2018; 29(Suppl 9): ix173-ix178.

[30] European Medicines Agency. Rozlytrek. Amsterdam, 31/07/ 2020. Available from: https://ema.europa/en/medicines/ human/EPAR/rozlytrek [accessed: July 31, 2020].

[31] Doeble RC, Drilon A, Paz-Ares L, et al. Entrectinib in patients with advanced or metastatic NTRK fusion-positive solid tumours: integrated analysis of three phase 1-2 trials. Lancet Oncol. 2020; 21(2): 271-282. [Erratum: Lancet Oncol. 2020; 21(2): e70.] [Erratum: Lancet Oncol. 2020; 21(7): e341.] [Erratum: Lancet Oncol. 2020; 21(8): e372.]

[32] Ziegler DS, Doz F, Geoerger B, et al. Activity of larotrectinib in TRK fusion cancer patients with primary central nervous system tumours. Ann Oncol. 2019; 30(Suppl 9): ix124.

[33] Siena S, Doebele RC, Shaw AT, et al. Efficacy of entrectinib in patients with solid tumors and central nervous system metastases: integrated analysis from three clinical trials. J Clin Oncol. 2019; 37(15 Suppl): Abstract 3017.

[34] Russo M, Misale S, Wei G, et al. Acquired resistance to the TRK inhibitor entrectinib in colorectal cancer. Cancer Discov. 2016; 6: $36-44$.

[35] Cocco E, Schram AM, Kulick A, et al. Resistance to TRK inhibition mediated by convergent MAPK pathway activation. Nat Med. 2019; 25: 1422-1427.

[36] National Library of Medicine. Selitrectinib. Available from: pubchem.ncbi.nlm.nih.gov/compound/Selitrectinib [accessed: August 19, 2020].

[37] National Library of Medicine. Repotrectinib. Available from: pubchem.ncbi.nlm.nih.gov/compound/Repotrectinib [accessed: August 19, 2020].
[38] Hyman DM, Kummar S, Farago AF, et al. Phase I and expanded access experience of LOXO-195 (BAY 2731954), a selective next-generation TRK inhibitor (TRK). In: Proceedings of the 110th Annual Meeting of the American Association for Cancer Research, March 29-3 April 2019, Atlanta, GA (Abstract 127).

[39] Drilon A, Ou SI, Cho BC, et al. Repotrectinib (TPX-0005) is a next generation ROS1/TRK/ALK inhibitor that potently inhibits ROS1/TRK/ALK solvent-front mutations. Cancer Discov. 2018; 8: 1227-1236.

[40] A study of repotrectinib (TPX-0005) in patients with advanced solid tumors harboring ALK, ROS1, or NTRKI-3 rearrangements (TRIDENT-1). Available from: https://clinicaltrials. gov/ct2/show/NCT03093116 [accessed: August 19, 2020].

[41] Drilon A, Zhai D, Deng W, et al. Repotrectinib, a next generation TRK inhibitor, overcomes TRK resistance mutations including solvent front, gatekeeper and compound mutations. In: Proceedings of the 110th Annual Meeting of the American Association for Cancer Research, March 29-April 3, 2019. Atlanta, GA (Abstract 4000).

[42] Turning Point Therapeutics reports early interim data from registrational phase 2 TRIDENT-1 study of repotrectinib, provides regulatory update. August 19, 2020. Available from: https:// ir.tptherapeutics.com/news-releases/news-release-details/turning-point-therapeutics-reports-early-interim-data/ [accessed: August 19, 2020]

[43] Klein R, Smeyne RJ, Wurst W, et al. Targeted disruption of the trkB neurotrophin receptor gene results in nervous system lesions and neonatal death. Cell 1993; 75: 113-122.

[44] Yeo GS, Connie Hung CC, Rochford J, et al. A de novo mutation affecting human TrkB associated with severe obesity and developmental delay. Nat Neurosci. 2004; 7: 1187-1189.

[45] Xu B, Goulding EH, Zang K, et al. Brain-derived neurotrophic factor regulates energy balance downstream of melanocortin- 4 receptor. Nat Neurosci. 2003; 6: 736-742.

[46] Yamada K, Nabeshima T. Brain-derived neurotrophic factor/ TrkB signaling in memory processes. J Pharmacol Sci. 2003; 91: 267-270.

[47] Drilon A, Siena S, Ou SI, et al. Safety and antitumor activity of the multitargeted pan-TRK, ROS1, and ALK inhibitor entrectinib: combined results from two phase I trials (ALKA-372-001 and STARTRK-1). Cancer Discov. 2017; 7: 400-409.

(Kiss Edina dr., Budapest, Podmaniczky u. 111-113., 1062 e-mail: edina.kiss.dobos@gmail.com)

A cikk a Creative Commons Attribution 4.0 International License (https://creativecommons.org/licenses/by/4.0/) feltételei szerint publikált Open Access közlemény, melynek szellemében a cikk bármilyen médiumban szabadon felhasználható, megosztható és újraközölhető, feltéve, hogy az eredeti szerző és a közlés helye, illetve a CC License linkje és az esetlegesen végrehajtott módosítások feltüntetésre kerülnek. (SID_1) 